\title{
Martin Luther: music and mission
}

\author{
John Swarbrick
}

The Revd John Swarbrick is a Vice-President and Director of Music of the Methodist Sacramental Fellowship, and a Methodist Presbyter in the Harrow and Hillingdon Circuit.

mjswarbrick@btinternet.com

Harrow, UK

This article seeks to demonstrate Martin Luther's often-overlooked credentials as a musician. Luther was convinced that music was the viva voce evangelii (living voice of the gospel), and unlike other more radical Reformation movements, he encouraged the use of choral and congregational singing in worship. Some of his familiar hymns - Nun freut euch, Ein' feste Burg and Aus tiefer Not - offer insights into his ambitions to embed congregational singing into his vision of reformed worship, which went hand in hand with liturgical reform. Luther's Formula Missae and the vernacular Deutsche Messe lay the groundwork for Lutheran worship, which restructured the service around the centrality of the gospel proclamation. Luther's musical tradition reached its zenith in the work of J. S. Bach, which continues to echo in the Western musical canon, leaving Luther with a lasting musical legacy.

MARTIN LUTHER • MUSIC • REFORMATION • J. S. BACH • ORGAN MUSIC • LITURGY 
This lecture was delivered at the Methodist Sacramental Fellowship Meeting during the Methodist Conference of 2017 in Birmingham, UK, and is published here with the kind permission of the MSF editors, the Revds Norman and Margaret Wallwork. Hard copies are available at $£ 3.50$ (including postage) from 6 Exmoor Close, Tiverton EX16 6UR, and details of the Methodist Sacramental Fellowship and its other publications can be found at www.sacramental.org.uk. This lecture is best read alongside the playlist of recorded music, which can be found in the Appendix.

\section{Recorded music: Mendelssohn, Symphony no. 5 in D, op. 107, fourth movement}

The fourth movement of Mendelssohn's Fifth Symphony is not a conventional symphonic finale, more a fantasia on Luther's hymn Ein'feste Burg ist unser Gott (A mighty fortress is our God). The German poet Heinrich Heine called Ein'feste Burg the 'Marseillaise of the Reformation'. 'Marseillaise' is a word that puts us in mind of revolution, though it would be fair to say that Luther prosecuted revolution by stealth. This year's Proms marked the quincentenary of the beginning of the Reformation in 1517 with a performance of Mendelssohn's Fifth Symphony as part of a season in which the Reformation's musical legacy featured prominently. This included three concerts on Sunday 20 August, marketed as 'Reformation Day', and ended with a performance of J. S. Bach's St John Passion; and, a week later, with a concert devoted to music inspired by the fifteenth-century Bohemian Reformation led by Jan Hus (c. 1372-1415). Fittingly, it began with the Hussite chorale 'You who are warriors of God' (Ktož jsú Boži bojovníci).

Well, revolutionary defiance expressed in music comes in many forms: this year's Proms season also marked the centenary of that other October revolution - the one that erupted in St Petersburg in 1917. Shostakovich's Twelfth Symphony, subtitled 'The Year 1917', is one of several Soviet-era works featured in this well-planned season.

But for present purposes, back to Mendelssohn's Fifth. It's a good place to start, in more ways than one. Felix Mendelssohn (1809-47) came from a famous mercantile Jewish family that had converted to Lutheran Christianity, though that didn't save his music from proscription under the Nazis. His fifth and final symphony was composed in 1829 and was intended for a celebration planned in Germany for the following year to mark the tercentenary of the Augsburg Confession, the primary doctrinal statement of the Lutheran faith agreed at the Diet of Augsburg in June 1530. In the event, the anniversary celebration 
never took place, and Mendelssohn finally released the symphony for public performance in 1832. It was published only after his death - and, to add to the confusion, it was chronologically his fourth symphony! Now why start here? Because Mendelssohn's homage to Luther demonstrates the reach of hymnody in German culture, its contribution to a sense of national identity long before there was a single German state, and the Lutheran Reformation's long-term influence on the development of German music - classical, pop and rock.

Martin Luther: Augustinian friar, theologian, preacher, anti-Semite, ${ }^{2}$ pugnacious controversialist, uxorious family man, master of the new media of print and pamphlets - but few would add 'musician' to this list. Regrettably, that includes the contributors to The Cambridge Companion to Martin Luther, ${ }^{3}$ which contains no study of his liturgical reforms, his hymns or his understanding of music. But I suspect that this may be par for the course for church historians and systematic theologians for whom music is merely a side dish to accompany the main course. And as for the popular image, I hate to disappoint you, but Luther probably did not wake up one morning and decide to hammer his Ninety-Five Theses to the door of the Castle Church at Wittenberg on 31 October 1517. What he actually did was to publish and circulate the Theses as a pamphlet, in Latin, intended not for a readership of local laypeople, but as a starting point for a debate with his clerical colleagues about the abuses of the system of indulgences. 'Wrong but wromantic', to adapt Sellar and Yeatman in 1066 and All That. ${ }^{4}$ It is closer to the truth to say that with the Theses Luther nailed his colours to the mast rather than to the church door.

The controversy over indulgences, Luther's excommunication by Pope Leo $\mathrm{X}$, his subsequent summons before the Diet of Worms in 1521 and refusal to recant - 'Here I stand; I can do no other' (a good soundbite, but again apocryphal) - all marked a turbulent sequence of events for a turbulent priest, though there was a happy issue out of all these afflictions when Frederick III ('Frederick the Wise'), the sympathetic Elector of Saxony, spirited Luther away to safety in the Wartburg castle at Eisenach. It was a brief, voluntary incarceration, but it released a torrent of creativity over the next few years, including: the translation of the New Testament from the Greek, not the Vulgate, into German in 1522; the Formula Missae (a first draft for liturgical reform) in 1523; the Achtliederbuch (the first German hymn book) in 1524; and the Deutsche Messe (the reformed German-language Mass) in conjunction with the composer Johann Walter in 1525-26. The Old Testament and Apocrypha were more a team effort, but were completed in 1534. It is not an exaggeration to say that Luther's translation of the Bible has the equivalent cultural status in 
Germany to that of the King James Version in anglophone countries - and it remains even today the standard version for German Protestants.

That's a brief and necessarily selective introduction. Let's turn to the Reformer and music. For Luther Musica praedicavit evangelium - 'Music preaches the gospel.' It is this proclamation that distinguishes Luther's Reformation from the more radical reformations that were evolving in cities like Geneva, Zurich, Basel and Strasbourg. On the basis of sola scriptura the Reformed churches in Switzerland, France and southern Germany restricted congregational music to the singing of the psalms. Instruments were forbidden. The most radical suppression was in Huldrych Zwingli's Zürich where there was musical silence in church from the 1520s until the 1590s.

Luther the young Augustinian friar had absorbed the best of his own tradition well. Augustine of Hippo regarded music as a preparation for the gospel - in the sense that it was a part of God's providential care in drawing humankind towards the divine vision (visio Dei) - though it has to be said that he, like other patristic authors, had an ambivalent attitude towards the use of music in worship, observing that:

when I recall the tears which I shed at the song of the Church in the first days of my recovered faith, and even now as I am moved not by the song but by the things which are sung when sung by fluent voice and music that is most appropriate, I acknowledge again the great benefit of the practice. Thus I vacillate between the peril of pleasure and the value of the experience, and I am led more - while advocating no irrevocable position - to endorse the custom of singing in church so that by the pleasure of hearing the weaker soul might be elevated to an attitude of devotion. Yet when it happens to me that the song moves me more than the thing which is sung, I confess that I have sinned blamefully and then prefer not to hear the singer. ${ }^{6}$

John Calvin shared the same hesitations. Luther, however, did not: he took Augustine's insight a stage further, claiming that the gospel itself is effectively heard and known in music and is also a means of its proclamation.

Music was part of Luther's life from his early days. He absorbed an initial love of it from his parents. At around the age of seven he entered the Latin school at Mansfeld. Even for such young children, it was a rigorous educational regime, 
initiating them into the three core subjects of the medieval trivium: grammar, logic and rhetoric. But the study of Latin was allied with the study of music. An emphasis on practical aspects of music like notation and sight-singing, with a smattering of instruction in music theory and the rudiments of Gregorian chant, gave Luther the ability to sing the liturgical texts that he and his school friends would have sung in St George's Church Sunday by Sunday.

In 1497, Luther was sent to the Latin cathedral school at Magdeburg and lived with the Brethren of the Common Life, a quasi-monastic community that promoted a simple, practical spirituality; here his studies continued in a similar vein - more Latin grammar, some logic and rhetoric, as well as music that would enable him to sing the services in the cathedral. But after only a year at Magdeburg, he was sent to a similar school at Eisenach where this pattern of education was continued. These years were formative, as he became more familiar with the cycle of music sung throughout the liturgical year, and it took deep root in him.

He matriculated at Erfurt University when he was 18 and embarked not only on the trivium but also on the quadrivium. In other words, to grammar, logic and rhetoric were added arithmetic, geometry, music and astronomy. At Erfurt he was part of what we would now call a cohort of musically talented undergraduates, some of whom became firm friends and subsequent associates in the Reformation movement. Here he extended his knowledge of popular folksong (Volkslieder), studied simple counterpoint and composition, and became a proficient lutenist. But a potential career in the law that his father intended for him was abandoned in response to a call to the monastic life; and in 1505 Luther was professed as a monk, entering the monastery of the Augustinian Hermits at Erfurt. Here he was immersed in the music of the daily offices, was ordained priest, and gave his spiritual adviser Johann von Staupitz a torrid time in the confessional with his exacting and over-scrupulous conscience.

Staupitz hit on a brilliant way to channel Luther's Anfechtungen in a more creative direction: he suggested that Luther should go off and teach theology at the recently founded University of Wittenberg. In 1508 he was appointed professor of moral philosophy and later, on completion of his doctorate, professor of biblical exegesis - a post he held until his death in 1546. Academic life was complemented by the university's rich musical life. The university's founder, the Elector Frederick the Wise, had a keen interest in music and lavished resources on the court chapel, which also doubled up as the university 
church. In 1508, the year Luther arrived at Wittenberg, 31 clergy and musicians were responsible for the music; by 1520 the numbers had doubled. New sets of partbooks were produced for the singers, including music by such prominent early sixteenth-century Flemish composers as Josquin, Jacob Obrecht and Heinrich Isaac. The other significant point was that the study of music at Wittenberg was shifting from musica theoretica to musica practica - in other words, less philosophical speculation on the music of the spheres and more emphasis on music as a practical skill and art.

In this résumé of his education and scholarly achievements lies the key to what Luther later hoped to achieve in the Reformed ecclesiology to which history has appended his name. His love of music was for itself, but it also had a catechetical, liturgical and missionary purpose. But how about some of his own words on this subject rather than mine? I jump ahead a bit here to this extract from a letter he wrote to the Swiss composer Ludwig Senfl in October 1530, during his second period of voluntary detention for his own safety in Coburg Castle. The context is the Diet of Augsburg of that year when the confessional standards of the Lutheran Church in their studious moderation were codified and agreed. Luther writes:

\begin{abstract}
Although my name is so hated that I must fear, my dear Ludwig, that this letter will not be safely received and read by you, yet my love of music has overcome my fear, and in musical talent, I see that God has richly endowed you ... We know that music is hateful and intolerable to devils. I really believe, nor am I ashamed to assert, that next to theology there is no art equal to music, for it is the only one, except theology, which can give a quiet and happy mind, a manifest proof that the devil, the author of racking care and perturbation, flees from the sound of music as he does from the exhortation of religion. This is the reason why the prophets practised no other art, neither geometry nor arithmetic nor astronomy, as if they believed music and divinity nearly allied; as indeed they declare in their psalms and canticles. Praising music is like trying to paint a great subject on a small canvas, which turns out merely a daub. But my love for it abounds; it has often refreshed me and freed me from great troubles. ${ }^{7}$
\end{abstract}

This friendship survived despite the confessional differences that remained between them. Senfl continued writing music for the adornment of the 
Catholic liturgy, but two of the pieces he composed at this time show in the first case diplomatic tact and in the second a deft personal tribute. The first was a setting of Psalm 133, Ecce quam bonum, to be sung at the opening of the Diet ('Behold how good and pleasant it is to dwell together in unity'); and the second was a motet on verse 17 from Luther's favourite psalm, Psalm 118: Non moriar, sed vivum et narrabo opera Domini (I shall not die but live and declare the works of the Lord) - a text that meant so much to Luther that it became in effect his motto.

\section{Recorded music: Ludwig Senfl, Motet Non moriar, sed vivum et narrabo opera Domini}

Interestingly, Luther wrote his own more modest setting of this same text in a motet published at Wittenberg in 1545, the year before his death. His letter to Senfl was not the only example of his claim that 'next to theology there is no art equal to music'; he repeated it on a number of occasions and in different contexts. However, the portion of the letter we heard rehearses a number of themes which he was later to develop in a proposed treatise on music, of which he wrote only a draft outline.

Let us take a step back to some of the practical outworkings of Luther's understanding of the role of music in worship and Christian formation. Senfl's cool, elegant polyphony was fine for trained choirs, but it was never going to be the stuff of popular congregational participation. Congregational participation was certainly a primary goal for Luther's reformation of worship, but he envisaged it as one element alongside choral and instrumental, especially organ, music. What we now typically think of as a Lutheran chorale (choral in German) was, in those early years, something closer to a unison chant rather than to a harmonised melody. The word 'chorale' itself evolved from the common term for Gregorian chant and could be sung in unaccompanied unison (choraliter) or in polyphonic settings (figuraliter) by a choir. Many chorale melodies were developed from specific Gregorian chants; for others new tunes were written - some adapted from secular folksong (Volkslied), but certainly by no means all. Other chorales were new versions in German of Latin office hymns, for example the Advent hymn Nun komm der Heiden Heiland from Veni, redemptor gentium. Metrical versions of the psalms and canticles were also added to the repertory. Like all liturgical innovations, it took some time for Lutheran congregational singing to become custom and practice. The early hymn books were written with choirs rather than congregations in mind. 


\section{John Swarbrick}

In 1524, the first collection of chorales was published, a slim volume of eight hymns entitled the Achtliederbuch, including four by Luther himself, one of which is Nun freut euch, lieben Christen gemein or 'Dear Christians, one and all, rejoice, with exultation springing'. In the Achtliederbuch it is headed 'A Fine Spiritual Song, How a Sinner Comes to Grace'. This ten-verse hymn in the translation by Richard Massie (1800-87) appears in the 1978 Lutheran Book of Worship. $^{8}$

Hymn: 'Dear Christians, one and all, rejoice', to the tune 'Nun freut euch'

1 Dear Christians, one and all, rejoice,

With exultation springing,

And, with united heart and voice

And holy rapture singing

Proclaim the wonders God has done,

How his right arm the victory won,

What price our ransom cost him!

2 Fast bound in Satan's chains I lay,

Death brooded darkly o'er me,

Sin was my torment night and day;

In sin my mother bore me.

But daily deeper still I fell;

My life became a living hell,

So firmly sin possessed me.

3 My own good works all came to naught,

No grace or merit gaining;

Free will against God's judgement fought,

Dead to all good remaining,

My fears increased till sheer despair

Left only death to be my share;

The pangs of hell I suffered.

4 But God had seen my wretched state

Before the world's foundation

And, mindful of his mercies great,

He planned for my salvation. 
He turned to me a father's heart;

He did not choose the easy part,

But gave his dearest treasure.

5 God said to his belovèd Son:

"Tis time to have compassion.

Then go, bright jewel of my crown,

And bring to all salvation;

From sin and sorrow set them free;

Slay bitter death for them that they

May live with you forever.'

6 The Son obeyed his Father's will,

Was born of virgin mother;

And, God's good pleasure to fulfil,

He came to be my brother.

His royal pow'r disguised he bore,

A servant's form, like mine, he wore,

To lead the devil captive.

7 To me he said: 'Stay close to me,

I am your rock and castle.

Your ransom I myself will be;

For you I strive and wrestle;

For I am yours, and you are mine,

And where I am you may remain;

The foe shall not divide us.

8 'Though he will shed my precious blood,

Of life me thus bereaving,

All this I suffer for your good;

Be steadfast and believing.

Life will from death the vict'ry win;

My innocence shall bear your sin;

And you are blest forever.

9 'Now to my Father I depart,

From earth to heav' $n$ ascending,

And, heav'nly wisdom to impart, 
The Holy Spirit sending;

In trouble he will comfort you

And teach you always to be true

And into truth shall guide you.

10 'What I on earth have done and taught

Guide all your life and teaching;

So shall the kingdom's work be wrought

And honoured in your preaching.

But watch lest foes with base alloy

The heav'nly treasure should destroy;

This final word I leave you.'

Martin Luther

trans. Richard Massie (1800-87) ${ }^{9}$

Textually, we have a hymn written in the first person, suggesting that here Luther may be in autobiographical mode. In the Lutheran Book of Worship it is placed in the section on 'Justification', offering a commentary in verse on the doctrine of justification that had been Luther's great theological breakthrough in the years before the indulgences controversy of 1517; in addition, it is also a skilful commentary on Romans $1-8$; and, finally, it is strongly Trinitarian in character. Musically, we have a tune composed by the author of the words, though not in its rhythmically freer, original version. This should not surprise us, as Lutheran congregations did what all congregations do when faced with singing complex rhythms and syncopations: they tend to make them rhythmically more regular, predictable and four-square. The other significant change in performance practice was to transfer the tune in chorales from the tenor of monastic plainsong to the soprano line for a congregation of women, men and children.

In the interests of authentic/period performance practice we can sing Ein'feste Burg ist unser Gott in something closer to its original form - something with the melodic fluidity of Gregorian chant. First, a little background to Luther's great Reformation battle cry. We can't be certain exactly when Luther wrote it probably at some point between 1527 and 1529 - or for what occasion, though the most probable answer was for the 1529 Diet of Speyer when the Lutheransympathising free cities and princes of the Holy Roman Empire lodged their formal 'protest' against the Catholic majority. This wasn't just a political 
manoeuvre, but reflected the genuine growth in adherence to Luther's reform movement. However, Heinrich Heine's description of it as the 'Marseillaise of the Reformation', sung as Luther and his friends entered Worms in 1521, is just a little too good to be true, though its themes of defiance of authority, contempt for 'the devil and all his works', awareness of one's own weakness, and an absolute and joyous trust in God is spot on. The text is based, loosely, on Psalm 46, with a couple of sideways glances at 1 Peter 5:8, a translation not as familiar as the one by Thomas Carlyle, but the one used in the Lutheran Book of Worship of $1978 .^{10}$

Hymn: 'A mighty fortress is our God', to the tune 'Ein' feste burg ist unser Gott'

1 A mighty fortress is our God, a sword and shield victorious;

he breaks the cruel oppressor's rod and wins salvation glorious.

The old satanic foe, has sworn to work us woe!

With craft and dreadful might he arms himself to fight. On earth he has no equal.

2 No strength of ours can match his might!

We would be lost, rejected.

But now a champion comes to fight, whom God himself elected.

You ask who this may be?

The Lord of hosts is he!

Christ Jesus, mighty Lord, God's only Son, adored.

He holds the field victorious.

3 Though hordes of devils fill the land all threat'ning to devour us, we tremble not, unmoved we stand; they cannot overpow'r us. Let this world's tyrant rage; in battle we'll engage! 
His might is doomed to fail;

God's judgement must prevail!

One little word subdues him.

4 God's word forever shall abide, no thanks to foes, who fear it; for God himself fights by our side with weapons of the Spirit. Were they to take our house, goods, honour, child, or spouse, though life be wrenched away, they cannot win the day.

The kingdom's ours forever. ${ }^{11}$

By way of relaxation, we have what J. S. Bach (1685-1750) makes of the sentiment and the chorale melody from his church cantata Ein' feste Burg ist unser Gott, BWV 80. It's an early work from his time as court composer at Weimar when a version of it was sung during the church service for the Third Sunday in Lent; he later revised and expanded it when he was at Leipzig; and we know that it was sung on at least two occasions for the feast of the Reformation in 1723 and in 1735 . Here is the fifth movement, a vigorous choral piece that sets the words of verse three of the chorale - with bubbling strings and festive trumpets to accompany the triumphalist text:

And were this world all devils o'er,

and watching to devour us,

we lay it not to heart so sore;

nor they can overpower us.

And let the prince of ill

look grim as e'er he will,

he harms us not a whit;

for why? His doom is writ;

a word shall quickly slay him. 


\section{Recorded music: Johann Sebastian Bach, Cantata BWV 80, fifth movement}

If Ein' feste Burg is Luther's most famous hymn, it is closely followed by his paraphrase of Psalm 130, Aus tiefer Not schrei ich zu dir (Out of the depths I cry to thee). Written in 1523, it was one of his first hymns. A four-stanza version was included in the Achtliederbuch of 1524 and a five-stanza version was published in a hymn book by his friend and collaborator, the composer Johann Walter, in the same year. The shorter version remains closer to the text of the psalm; the longer version explores more fully the theme of grace rather than works. Because Psalm 130 was one of the appointed psalms in the traditional funeral service, it is perhaps no surprise to learn that in Luther's paraphrase it was sung at the funeral of the Elector Frederick the Wise in 1525, and 21 years later, in 1546, at Luther's own funeral. As early as 1537 it had found its place in the lectionary in the town church at Naumberg as the gradual hymn (between the Epistle and the Gospel) for the Twenty-Second Sunday after Trinity.

We know it best in the translation by Catherine Winkworth (1827-78), a skilled nineteenth-century translator of German hymns. Like Luther, she also produced two versions of the hymn: the earlier one, originally published in a collection entitled Lyra Germanica (1855), has appeared in Methodist hymn books since 1877; the second kept to the metre of Luther's original text and the chorale melody that goes with it, and was published in her Chorale Book for England (1863). A new tune, 'St Martin', composed by James Sheppard (1835-79), was composed for the version with which we are now familiar.

This superb hymn is more than a metrical version of Psalm 130: it alludes to a wide range of Old and New Testament texts as well, and comes across as a profound and personal expression of Luther's own understanding of the doctrine of justification. But it had another function beyond its use in funeral services: it was sung as a catechism hymn because of the way in which it expounds the doctrine of justification; and this exposition found an echo in Luther's Shorter Catechism. In a popular catechetical guide published in 1581, a later Lutheran writer noted:

This fifth main part of the holy catechism with its questions and answers the children at home can rehearse and practise after breakfast and after the Gratias has been said. Following the evening meal, and after the Gratias has been said, the children at the table can pray out of 'David's Catechism' Psalm 51 ... and thereafter sing ... from Luther's hymnbook, Aus tiefer Not schrei ich zu dir. ${ }^{12}$ 
I'm not sure such an approach would go down well with Young Church today, but we at least can have a little more insight into how Luther believed that one of the best ways to learn the faith was to sing it.

Hymn: 'Out of the depths I cry to thee'13

1 Out of the depths I cry to thee, Lord God! O hear my prayer! Incline a gracious ear to me, And bid me not despair: If thou rememberest each misdeed, If each should have its rightful meed, Lord, who shall stand before thee?

2 'Tis through thy love alone we gain

The pardon of our sin;

The strictest life is but in vain,

Our works can nothing win;

That none should boast himself of aught, But own in fear thy grace hath wrought

What in him seemeth righteous.

3 Wherefore my hope is in the Lord,

My works I count but dust;

I build not there, but on his word,

And in his goodness trust.

Up to his care myself I yield, He is my tower, my rock, my shield,

And for his help I tarry.

4 And though it linger till the night,

And round again till morn, My heart shall ne'er mistrust thy might,

Nor count itself forlorn.

Do thus, O ye of Israel's seed, Ye of the Spirit born indeed,

Wait for your God's appearing. 
5 Though great our sins and sore our wounds,

And deep and dark our fall,

His helping mercy hath no bounds,

His love surpasseth all:

Our trusty loving Shepherd, he

Who shall at last set Israel free

From all their sin and sorrow.

Martin Luther (1483-1546)

trans. Catherine Winkworth (1827-78)

based on Psalm 130

Examples such as Nun freut euch, Ein' feste Burg and Aus tiefer Not offer us insights into Luther's ambitions to embed congregational singing into his vision of Reformed worship. But hymns were only part of a wider strategy for this reform; they went hand in hand with liturgical reform. There is a sense in which everything he did was a response to his understanding of justification by faith alone: this lies, I think, at the heart of every theological question and every practical expression. He was at one and the same time a conservative and a radical liturgical reformer. We see this in his first attempt to reform the liturgy, the Formula Missae of 1523. Don't force through too much change too quickly. Keep the Latin, the candles, the incense and the vestments - the familiar liturgical landmarks; but read the Scriptures in German, preach in German, sing hymns in German, and strip the canon (the Eucharistic Prayer) of anything that smacks of the language of eucharistic sacrifice - or in Luther's words that 'great abomination and blasphemy that papistic idol ... namely, the Mass and the other abuses of the sacrament. ${ }^{14}$ Against that background, the preaching and teaching of justification will touch more receptive rather than antagonised ears.

It meant the drastic pruning of the canon of the Roman Mass - in other words the Eucharistic Prayer - to the Preface, which included the Words of Institution, the singing of the Sanctus, the Benedictus, during which the elevation took place, followed by the giving of the bread and the wine, during which the Agnus Dei was sung. Luther's aim was to replace the traditional understanding of the celebrant making an offering to God with a diametrically opposite dynamic: it is all about God's gift to us. In his 'Admonition Concerning the Sacrament' (1530), he wrote: 
Doing this is set forth briefly and surely in these words: 'Do this in remembrance of me.' Learn to remember him ... in preaching, praising, honouring, listening, and giving thanks for grace revealed in Christ. If you do that ... you have given nothing to God, nor are you able to, but you have and receive each and every thing from him, particularly eternal life and [the] infinite righteousness of Christ ... For this is the true God who gives and does not receive, who helps and does not let himself be helped ... in short, he does and gives everything, and he has the need of no one; he does all things freely out of pure grace without merit, for the unworthy and undeserving, yes, for the damned and the lost. This kind of remembrance, confession and glory he desires to have. ${ }^{15}$

The Formula Missae was not, however, the law of the Medes and the Persians; it was prepared for the pastor of the church at Zwickau, and intended as general guidance for him and other celebrants who were free to modify it ad libitum. It laid the foundations for the vernacular Deutsche Messe of 1526. This was more prescriptive, but prescriptive in a particular direction: 27 of its 49 pages are filled with musical notation; the remaining 22 pages include frequent reference to the musical aspects of the liturgy. Luther adopts the same approach to the canon, but it is the careful and consistent use of music which is astonishing: he uses plainchant in different modes (those medieval precursors of the major and minor scales with which we are more familiar) for different elements in the liturgy. There is an elegant, I would say almost organic, symmetry about this. In the earliest 1526 version, he takes modes 1 (Dorian), 5 (Lydian) and 6 (Hypolydian) and deploys them in this way:

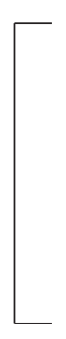

Kyrie

[ Gospel

Credo: Wir Glauben all an einen Gott

Words of Institution

Agnus Dei: Christe, du Lamm Gottes
Mode 1

Modes 5/6

Mode 1

Modes 5/6

Mode 1

Figure 1

The central aim is to give the same significance to the proclamation of the gospel as to the Words of Institution in the same Mode 5/6 either side of the 
confession of faith in the Creed in Mode 1. A few points to note: (1) there is no Gloria, because this original version was first trialled during Advent 1525; (2) we are starting to see German metrical versions of the standard liturgical texts in the Creed and the Agnus Dei; and (3) Luther was consulting musical colleagues.

By 1537 , to take just one example, the Deutsche Messe as celebrated in Naumberg has been expanded, and now includes the use of another mode, Mode 4 (Hypophrygian), but the underlying symmetry remains.

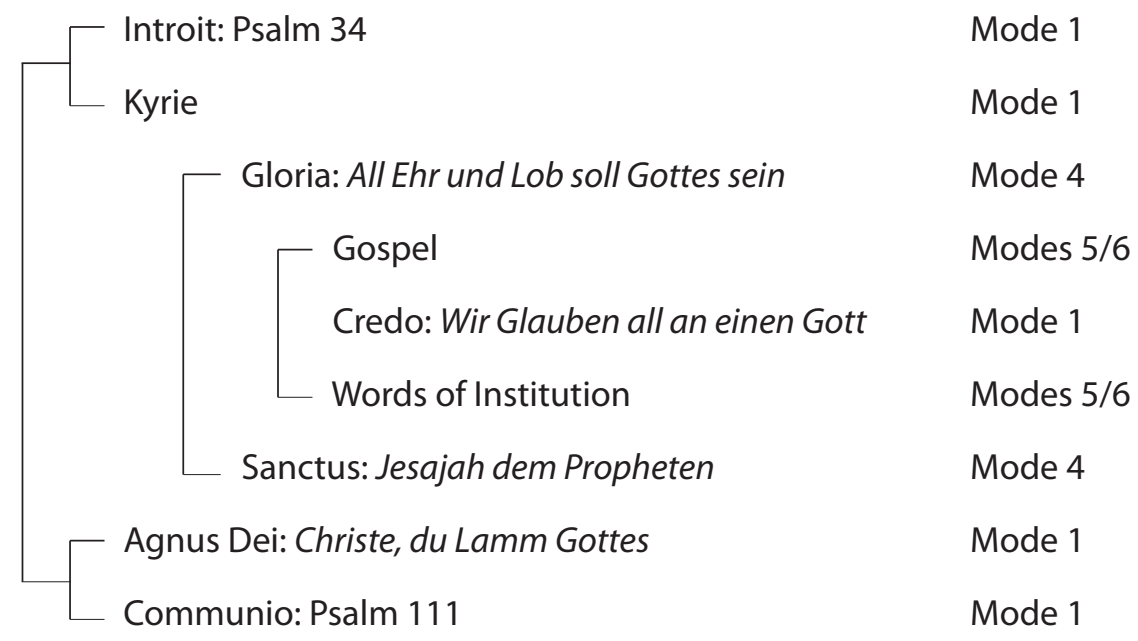

Figure $2^{16}$

Using Psalm 34 as an introit had familiar eucharistic associations, especially in verse 8: ' $O$ taste and see that the Lord is good.' Singing Psalm 111 during the administration of the elements referred back to the Words of Institution, especially in verse 4:'He has instituted a memorial of his wonders.'Luther's own metrical versions of the Gloria and the Sanctus were sung alongside congregational chorales. Some of these metrical versions of liturgical texts are still included in the Lutheran Book of Worship. There are 12 verses of Wir Glauben all an einen Gott, Luther's metrical version of the Nicene Creed. We can listen to the congregation of Roskilde Lutheran Cathedral in Denmark singing part of it in a recording that reconstructs what a Lutheran Mass for the Feast of the Epiphany might have sounded like under J. S. Bach's direction at St Thomas's Church, Leipzig in 1740. 
Recorded music: Wir Glauben all an einen Gott from J. S. Bach, Epiphany Mass

The Deutsche Messe provided a template for the development of Lutheran church music in the years that followed. We know from the liturgies devised by Luther's Wittenberg colleagues, as well as from the correspondence with one of his key lieutenants, Philip Melanchthon (1497-1560), that the Deutsche Messe was more of a guide than a chain. In villages, it was used in its simplest form, and sung mainly in German. In larger towns and cities, especially where there was a Latin school, the liturgy was a mixture of Latin and German, with more German in what we would call Ordinary Time and more Latin on high days and holidays. Successive editions of hymn books extended the repertory of chorales for congregations; vernacular chant was sung not only by the pastors, but by the people as well; and a rich tradition of polyphonic choral music was retained. Gradually, the role of the congregation was transformed from one of passive listening to active participation. That active participation required instrumental accompaniment: it came principally in the form of the organ - one of the most complicated machines of the early sixteenth century - and organ playing and the composition of music for the organ flourished.

Do not underestimate this. In 1705, the young J. S. Bach, then aged 20, walked the 400 kilometres from Arnstadt in Saxony, where he had been appointed organist at the Neukirche, to the Hanseatic port of Lübeck to hear the famous Dieterich Buxtehude (1637-1707) play the splendid three-manual organ with its 54 stops. ${ }^{17}$ What is sometimes called the North German organ tradition was still flourishing well into the nineteenth century, with the music of Mendelssohn, Max Reger (1873-1916) and Josef Rheinberger (1839-1901), and into the twentieth century with Paul Hindemith (1899-1963), though in the last century it is French composers who have dominated the organ repertory.

All these developments contributed to Luther's understanding of music as viva voce evangelii - the living voice of the gospel - using music as the medium to connect the preaching and teaching ministry of the Church. There were two related aspects to this process. First, to encourage the practice of singing for congregations and choirs, music became an integral part of children's education: as early as 1528, Philip Melanchthon drew up regulations for schools in Saxony, so that the curriculum included four hours of music teaching a week. Choir schools attached to churches flourished. Second, in a tradition that persisted over the next two centuries, it became customary for pastors and teachers to study music as well as theology, and for church musicians to study 
theology as well as music. If music was now to preach the gospel, then Luther's conviction inspired composers such as Michael Praetorius (1571-1621), Heinrich Schütz (1585-1672), Buxtehude and several generations of the Bach family, culminating in the work of Johann Sebastian, to write music for the Lutheran Church ad maiorem Dei gloriam - to the greater glory of God.

J. S. Bach's music for the Lutheran Church represents the zenith of this tradition. An orthodox Lutheran, but one drawn to Pietism - as all those arias in the cantatas and the St John and St Matthew Passions illustrate. And arguably, he was the supreme composer of the Christian Cross. I don't say that simply because the larger part of his output was composed explicitly for the Church; this is something that runs through his instrumental and secular vocal music as well. It has something to do with that perfect integration of the vertical and horizontal aspects of composition, themselves a metaphor of the Cross. By vertical, I mean the harmony - the chords, if you like. By horizontal, I mean counterpoint - the fluid independence of the lines, or'voices' as music theorists call them, though those'voices' can be human or instrumental. And there is an integration here: harmony cannot exist independently of counterpoint; and counterpoint cannot exist independently of harmony. Bach's music fuses harmonic logic, linear ecstasy and rhythmic energy, and exhibits a level of technical and expressive perfection which has influenced composers ever since - and a wider musical public since 1829, when Mendelssohn revived a version of the St Matthew Passion for public performance for the first time since the 1740s. For Bach all music, sacred or secular, was'a harmonious euphony for the glory of God and the instruction of my neighbour.' ${ }^{18}$

The Mass in B Minor was not and could not have been performed liturgically. Indeed, it is difficult to find evidence that it ever was performed in Bach's lifetime. I suspect he wrote it for God and for himself. But his four settings of the Lutheran Mass - Kyrie and Gloria only - certainly were; and when added to the extraordinary cycle of cantatas he composed for every Sunday in the liturgical year, they represent a towering achievement in the canon of Western music, and the culmination of Luther's conviction that music proclaims the gospel. In the formative years of his reform movement, they released ordinary people to sing a new world into being. His legacy has become the common currency of most Christian traditions where, at their best, hymns enable congregations to connect head, heart and voice, and sing the faith 'lustily and with good courage.' But it's not just about the Church: singing 'Abide with me' at a cup final as well as, shall we say, more demotic football chants, and political protest songs all draw on this same source, however unconsciously. 
All that said, if Bach's music does represent the zenith of this tradition in Germany, Scandinavia and further afield where Lutheranism took root, echoes of it continue to resonate down the centuries in the Western musical canon, though sometimes in unexpected contexts. A few weeks ago, I went to hear Leif Ove Andsnes and Marc-André Hamelin, two pianists at the top of their game, give a recital of music for two pianos at Wigmore Hall. The inestimable benefit of being a presbyter stationed in the Harrow and Hillingdon Circuit is the speed with which the Metropolitan Line conveys me to and from this home from home. One of the pieces they played was Debussy's En blanc et noir - a suite of three pieces composed in 1916 and inspired, according to the composer, by 'the greys of Velázquez' - a study in musical grisaille, if you like. Debussy was already ill with the cancer that would claim his life two years later in 1918 and, in his response to the Great War, was self-consciously styling himself Claude Debussy - musicien français.

The second movement of En blanc et noir is marked Lent, sombre. It is a threnody dedicated to a cousin of his publisher, Jacques Durand. Before his call-up, Lieutenant Jacques Charlot had worked for the family firm, the most distinguished of French music publishers, and had been killed in action in March 1915. It's a long time since I had heard this piece, and I confess I had forgotten how Debussy had expressed his anger and sadness at Charlot's death; but as we listen to it now, we shall hear the ghostly echoes of a familiar hymn tune. For Debussy it represented his fear that the war to end all wars would lead not only to the destruction of France and Germany, but also of their art and culture.

\section{Recorded music: Claude Debussy, En blanc et noir, second movement}

Luther would have been amazed not simply by the soundscape of early twentieth-century French music, but more significantly at the reach of his musical Reformation. That Reformation has extended well beyond the spiritual, pastoral and catechetical needs of a sixteenth-century religious revolution to become the common property of nearly all Christian traditions today; it has also flowed into the bloodstream of Western classical music and influenced the torch songs and anthems of popular music, too. Music, religious as well as nonreligious, may, in W. H. Auden's words, be the 'brandy of the damned', but is much more often to be experienced in the 'sudden mansion of any joy'19 - and for that latter insight we owe Luther a great debt. 


\section{Appendix}

The following recordings were used during the course of this lecture:

Mendelssohn, Symphony no. 5 in D, Op. 107, fourth movement

Warner Classics 0190295909109, CD 2, track 6

Ludwig Senfl, Motet Non moriar, sed vivum et narrabo opera Domini

CHE 0147-2, track 9

Johann Sebastian Bach, Cantata BWV 80, fifth movement

HMC 901326, track 17

Wir Glauben all an einen Gott from J. S. Bach, Epiphany Mass

Archiv 457 631-2, disc 1, track 24

Claude Debussy, En blanc et noir, second movement

$\mathrm{CDH} 55014$, track 2

The hymns from the Lutheran Book of Worship can be listened to at www.lutheran-hymnal.com/lbw/lbw_online.html

\section{Notes}

1. Quoted in Richard Watson and Kenneth Trickett (eds), Companion to Hymns and Psalms, Peterborough: Methodist Publishing House, 1988, p. 376.

2. Thomas Kaufmann, Luther's Jews: A Journey into Anti-Semitism, Oxford: Oxford University Press, 2017.

3. Donald K. McKim (ed.), The Cambridge Companion to Martin Luther, Cambridge: Cambridge University Press, 2003.

4. W. C. Sellar and R. J. Yeatman, 1066 and All That: A Memorable History of England, London: Methuen \& Co., 1930.

5. Ivor H. Jones, Music: A Joy for Ever, London: Epworth Press, 1989, p. 71.

6. From Augustine, Confessions, quoted in James McKinnon, Music in Early Christian Literature, Cambridge: Cambridge University Press, 1987, p. 155.

7. From a letter to Ludwig Senfl, 4 October 1530, quoted in E. G. Rupp and Benjamin Drewery, Martin Luther, London: Edward Arnold, 1970, p. 143.

8. No. 299 in the Lutheran Book of Worship (Minneapolis, MN: Augsburg, and Philadelphia, PA: Lutheran Church in America, 1978.

9. Lutheran Book of Worship, no. 299.

10. Lutheran Book of Worship, no. 228.

11. Lutheran Book of Worship, no. 299.

12. Bartholomäus Rosinus, Kurtze Fragen und Antwort über die Sechs Häupstücke deß heiligen Catechismi D. Martini Lutheri (1581), quoted in Robin A. Leaver, Luther's Liturgical Music: Principles and Implications, Grand Rapids, MI, and Cambridge: Eerdmans, 2007, p. 151. 
13. Hymns and Psalms, London: Methodist Publishing House, 1983.

14. Letter to the pastors at Lübeck in 1530, quoted in Leaver, Luther's Liturgical Music, p. 175.

15. Quoted in Leaver, Luther's Liturgical Music, p. 176.

16. See Leaver, Luther's Liturgical Music, pp. 168-168.

17. Malcolm Boyd, Bach, 2nd edn, Oxford: Oxford University Press, 1995, p. 22.

18. Quoted in Wilfrid Mellers, Bach and the Dance of God, London: Faber and Faber, 1980, p. 9.

19. W. H. Auden, 'Music is International', Collected Poems, London: Faber and Faber, 1976, pp. 340-341. 